\title{
IMPACT OF THE RIVERBED MORPHOLOGY ON THE SOURCE OF ORGANIC MATERIAL AND THE TROPHIC STRUCTURE OF FISH COMMUNITY ALONG THE UPPER REACHES OF THE NEVĖŽIS RIVER, LITHUANIA
}

\author{
Laurynas ČIVAS ${ }^{1 *}$, Vytautas KESMINAS ${ }^{1}$, and Rūta BARISEVIČIŪTÉ ${ }^{2}$ \\ ${ }^{1}$ Laboratory of Ecology and Physiology of Hydrobionts, Nature Research Centre, Vilnius, Lithuania \\ ${ }^{2}$ Department of Nuclear Research, State Research Institute—Centre for Physical Sciences and Technology, Vilnius, \\ Lithuania
}

Čivas L., Kesminas V., Barisevičiūtė R. 2016. Impact of the riverbed morphology on the source of organic material and the trophic structure of fish community along the upper reaches of the Nevèžis River, Lithuania. Acta Ichthyol. Piscat. 46 (4): 303-312.

Background. The catchment of the Nevėžis River, the sixth longest river in Lithuania, is among the most affected by agricultural activities. Although seriously disturbed by land reclamation and agricultural pollution, the Nevėžis River still has natural, anthropogenically unaffected stretches. Fish species were studied at two sites of the upper part of the river with different hydrological regime, exhibiting clear differences in the trophic status of fish. The combined effect of hydrogeomorphic and water-chemistry variability on the stable isotope composition of fish assemblages in Lithuania has not been investigated. The presently reported study was intended to explore the possible effects of the riverbed morphology and agricultural activities on the chemistry and stable isotope composition of the three main fish species.

Materials and methods. This study covered three species of freshwater fishes: the European perch, Perca fluviatilis Linnaeus, 1758; the roach, Rutilus rutilus (Linnaeus, 1758); and the northern pike, Esox lucius Linnaeus, 1758. The sampling was performed in both natural and regulated river stretches using backpack electrofishing equipment. Stable isotope composition of the samples was revealed by applying stable isotope analyses (SIA) with an elemental analyser connected to an isotope ratio mass spectrometer. To obtain more information about environmental variability and variation of stable isotopes $\delta^{13} \mathrm{C}$ and $\delta^{15} \mathrm{~N}$ in fish, the entire data matrix was analysed using Principal Component Analysis (PCA).

Results. In the study sites on the Nevėžis River, algal carbon isotope ratios were more ${ }^{13} \mathrm{C}$ - depleted than those from terrestrial sources. The fishes were clearly dependent on terrestrial carbon sources in natural locations. However, the fishes collected from regulated sites had carbon isotope signatures more similar to algal than to terrestrial sources. Mean values of $\delta^{15} \mathrm{~N}$ of the fishes from the natural sites were lower than those from the regulated ones.

Conclusion. The presently reported study revealed impact of abiotic habitat variables indicating the importance of physicochemical and morphological characteristics on $\delta^{13} \mathrm{C}$ and $\delta^{15} \mathrm{~N}$ isotopic values variance of fish at natural and regulated river sites. Our findings would help to evaluate and predict changes on river food webs that occur due to hydromorphological alterations determined by human activity and climate change. The results could be useful for fisheries, i.e., impact of environmental factors on fish nutrition and growth.

Keywords: food web, hydrogeomorphology, organic matter, C and N stable isotopes, water chemistry, perch, roach, pike

\section{INTRODUCTION}

Many rivers and streams have been channelized for various purposes. Channelization reduces the heterogeneity of physical habitats in rivers and streams (Bis et al. 2000, Pliūraite and Kesminas 2010) and is the most significant threat to the biodiversity and functioning of the river ecosystems worldwide (Rosenberg et al. 2000, Nakamura and Yamada 2005).
Stable isotopes are a useful tool for quantifying the energy and nutrient flow in ecosystems (Fry 2006, Jardine et al. 2006). When using stable isotopes in ecological research, the most common elements are carbon ratios $\left({ }^{13} \mathrm{C} \div{ }^{12} \mathrm{C}\right)$, whose isotopic signatures reveal the source material, and nitrogen ratios $\left({ }^{15} \mathrm{~N} \div{ }^{14} \mathrm{~N}\right)$, whose signatures reflect the trophic position of animals (Post 2002). Stable isotope analysis is a powerful analytical tool that complements classical studies because it provides

"Correspondence: Laurynas Čivas, Gamtos tyrimų centras, Akademijos g. 2, LT-08412 Vilnius, Lithuania, phone: +370 5269 76 53, e-mail: (LČ) laurynas.civas@gmail.com, (VK)v.kesminas@takas.lt, (RB) ruta.bariseviciute@ftmc.lt. 
data about the partitioning of nutrients to body tissues, revealing the source of the food that is assimilated rather than simply ingested (Trakimas et al. 2011).

Stable nitrogen isotope ratios in animals can serve as indicators of the trophic level because animals tend to be enriched in $\delta^{15} \mathrm{~N}$ by $3 \%-4 \%$ relative to the dietary ${ }^{15} \mathrm{~N}$ (Deniro and Epstein 1981, Minigawa and Wada 1984, Fry 1988). Elevated nitrogen isotope ratios in particular have been related to increasing eutrophication and pollution (Cabana and Rasmussen 1996, Costanzo et al. 2001, Savage and Elmgren 2004), whereas carbon isotope ratios (in littoral and pelagic environments) may depend more on the lake area (Post 2002) and/or the relative contributions of autochthonous and allochthonous organic matter (Grey et al. 2001).

For species that are unlikely to show appreciable dietary differences due to sex or habitat segregation, the approach could be particularly effective in revealing individual specialization, which has recently received more attention (Bolnick et al. 2003, Svanbäck and Persson 2004, Sánchez-Hernández et al. 2012, Pliūraite et al. 2013, Pilinkovskij et al. 2014). The European perch, Perca fluviatilis Linnaeus, 1758; the roach, Rutilus rutilus (Linnaeus, 1758); and the northern pike, Esox lucius Linnaeus, 1758 are common fish species in many central European rivers including the Nevėžis River. In addition, these species typically become more abundant with progressive river eutrophication leading to intensified competition for resources (Syväranta and Jones 2008). Each species was studied in two stretches of the upper part of the Nevėžis River with different hydrological regime, i.e., in natural and regulated stretches, exhibiting clear differences in the trophic status of fish.

Despite the strong influence of human activities in the basin, the Nevéžis River still supports a diverse ichthyofauna, composed of a mixed cool- to warm-water assemblages (Žiliukas 1999, Čivas et al. 2016). However, the dual influence of hydrogeomorphic and waterchemistry variability on the stable isotope composition of fish assemblages has not been investigated. In Lithuania, the stable isotope analysis of aquatic ecosystems was carried out only in the Curonian Lagoon (Lesutiene et al. 2007, 2008) and in some lakes (Rakauskas et al. 2013, Rakauskas 2014) for the purpose of ascertaining the role of invasive crustaceans in food webs.

The presently reported study was intended to explore the possible effects of the riverbed morphology and agricultural activities on the chemistry and stable isotope composition of three main fish species: perch, Perca fluviatilis; roach, Rutilus rutilus; and pike, Esox lucius. The goals of this study were: to estimate the natural abundance of stable carbon $\left({ }^{13} \mathrm{C} \div{ }^{12} \mathrm{C}\right)$ and nitrogen $\left({ }^{15} \mathrm{~N}\right.$ $\div{ }^{14} \mathrm{~N}$ ) isotopes in the main fish species representing different feeding guilds in the river; to assess and compare physicochemical characteristics in natural and regulated stretches of the river; to explore the influence of physical and chemical water parameters' variability on fish stable carbon and nitrogen isotopes; and to evaluate the relative contribution of basal energy sources, i.e., macroalgae and terrestrial detritus, to the nutrition of the main fish species.

\section{MATERIALS AND METHODS}

Study area. The study was conducted in July 2013 in the Nevéžis River in two sections: natural $\left(55^{\circ} 68^{\prime} \mathrm{N}, 24^{\circ} 45^{\prime} \mathrm{E} ; 151-159 \mathrm{~km}\right.$ of the river course) and regulated $\left(55^{\circ} 58^{\prime} \mathrm{N}, 24^{\circ} 62^{\prime} \mathrm{E} ; 183-175 \mathrm{~km}\right.$; Fig. 1). The criterion for distinguishing the sections was their riverbed morphology. In total, the studied stretch was $\sim 16 \mathrm{~km}$ long. The longitudinal distance between the investigated natural and regulated river stretches sites was $13 \mathrm{~km}$ of the river flow. To eliminate the impact of season and meteorology, samples of environmental variables, fish and primary sources were collected simultaneously, repeatedly three times for each site, during the same month, in July, when low stream flows facilitated effective sampling and largescale seasonal fish movement was unlikely to occur.

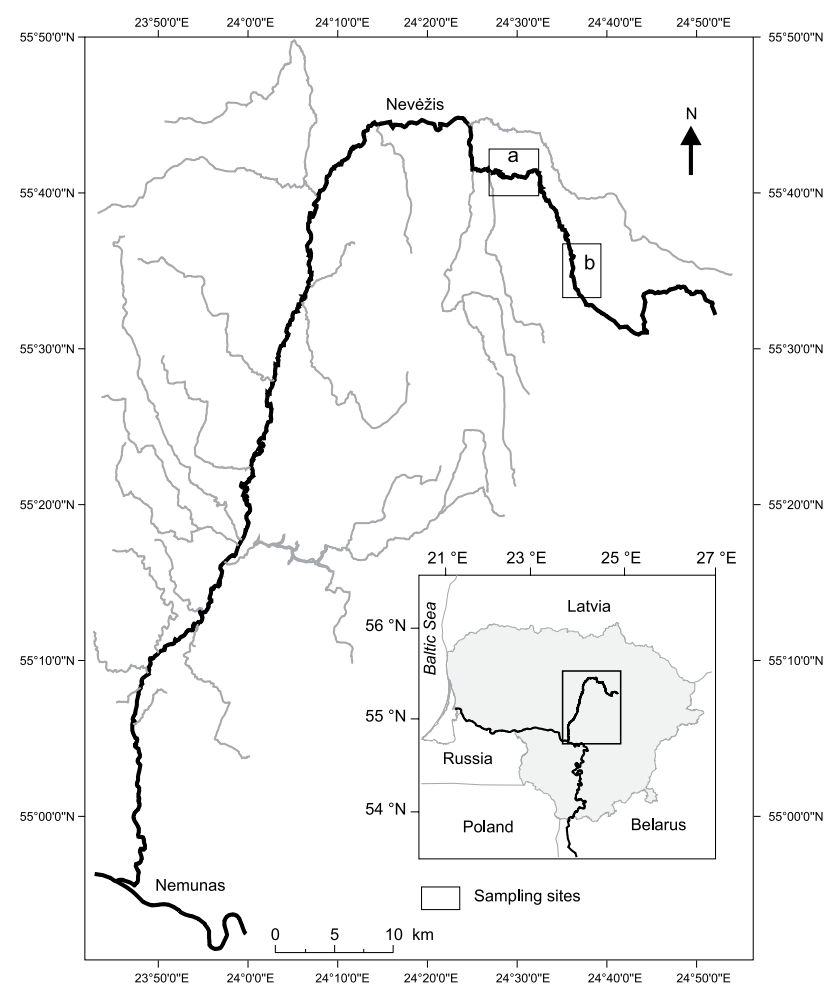

Fig. 1. Location of sampling stations on the Nevèžis River: $\mathrm{a}=$ natural stretch; $\mathrm{b}=$ regulated stretch

The Nevėžis River (the district of Panevėžys, central Lithuania) drains the catchment of $6141 \mathrm{~km}^{2}$ and flows for $210 \mathrm{~km}$ before merging with the Nemunas River (Fig. 1). It is one of the longest rivers in Lithuania, the fourth largest (by basin area), and one of those with the lowest elevation (Kilkus and Stonevičius 2011). In the upper part of the river valley, the Nevezžis River flows in the northwest direction. Some upper sections of the river are channelized. Industrial operations have led to both the water withdrawal and the elevated levels of inorganic substances in the water (Paukštys et al. 2011). Agricultural areas account for $\sim 45 \%$ of the catchment area, and $\sim 90 \%$ of this land is drained (Kilkus and Stonevičius 2011). Riparian areas are largely deforested although remnant riparian bands are quite common. Although seriously affected by land reclamation and agricultural pollution, 
the Nevėžis River still has natural, anthropogenically unaffected stretches. For the current research, we selected two stretches: natural and regulated. Thy are both located in the upper river reaches, between which there are no hydraulic barriers, with the exception of some $0.5 \mathrm{~m}$ high spillways for slowing down water.

Physicochemical characteristics. On each sampling site, 13 environmental variables were recorded (Table 1). All the environmental variables were measured or visually estimated on sampling sites along 12 evenly spaced transects using standardized procedures (Simonson et al. unpublished $\left.{ }^{*}\right)$. Biochemical oxygen demand $\left(\mathrm{BOD}_{7}\right)$ $\left(\mathrm{mg} \mathrm{O} \cdot \mathrm{L}^{-1}\right)$, total nitrogen $\left(\mathrm{mg} \cdot \mathrm{L}^{-1}\right)$, total phosphorus $\left(\mathrm{mg} \cdot \mathrm{L}^{-1}\right)$ concentrations, and total suspended solids (mg - $\mathrm{L}^{-1}$ ) were determined according to APHA (Anonymous 1985). Water sampling as well as in situ measurements of physicochemical parameters was performed in the subsurface of the mid-channel.

Wet river width $(\mathrm{m})$ and water depth $(\mathrm{m})$ were measured. Flow rate was estimated at four-tenths of the water depth above the stream bed using a flow meter (type Swoffer 2100). Water discharge $\left(\mathrm{m}^{-3} \cdot \mathrm{s}^{-1}\right)$, mean flow $\left(\mathrm{m}^{-1} \cdot \mathrm{s}^{-1}\right)$, and the maximum and mean depths $(\mathrm{m})$ were then calculated. The percentage of the riparian zone coverage (at the edge between the water channel and the banks) as well as that of its canopy over the water surface, aquatic vegetation, and substrate composition were estimated visually. The substratum class within each study location was classified and estimated visually (\%) according to Platts et al. (1983) as silt (particle size $<0.6 \mathrm{~mm})$, sand $(0.6-2.0 \mathrm{~mm})$, gravel $(2.0-20.0 \mathrm{~mm})$, pebble $(20.0-60.0 \mathrm{~mm})$, and stones (more than $60.0 \mathrm{~mm}$ ). Characteristics of the bottom substrate were presented in scores by coding classes in order of coarseness: $1=$ silt; $2=$ sand; $3=$ gravel; $4=$ pebble; $5=$ stones.
The channel width and $\mathrm{BOD}_{7}$ values did not differ between natural and regulated sites (Table 1). Canopy cover, flow velocity, and discharge values were lower on regulated than on natural sites. Water depth was considerably lower on natural than on regulated sites. The substrates of regulated sites differed from those of natural sites. Regulated sites had sand-silt substrates, whereas natural ones had pebble substrates. The highest values of suspended solids and macrophyte coverage parameters were recorded on regulated sites. Total nitrogen and total phosphorus concentrations on regulated sites in the Nevėžis River were greater than on natural sites. Descriptive statistics for the variables analysed can be found in Table 1, showing an array of conditions throughout the study area.

Fish surveys. Fish sampling was performed in both natural and regulated river stretches using backpack electrofishing equipment (HANS Grassl GmbH IG 200/2, Germany). Fish were sampled across the study reach performing single-pass electric fishing by wading upstream against the current (Arbačiauskas et al. 2009). All habitats were sampled, including riffles, lotic flats, and some oxbows. We collected fish species that appeared to be the most abundant on the study sites. All individuals were measured and the total length (TL), standard length $(\mathrm{SL})(\mathrm{mm})$, and weight $(W)(\mathrm{g})$ of each fish were recorded (Thoresson 1996).

Perch, roach, and pike were divided into two length classes (see Table 2) as it is known that these fish undergo ontogenetic niche shifts (Hjelm et al. 2000, Horppila et al. 2000, Svanbäck and Eklov 2002, Hjelm et al. 2003). In this study, roach and perch individuals $<150 \mathrm{~mm}$ and pike individuals $<250 \mathrm{~mm}$ were regarded as immature and were assigned to "group I" while mature individuals to "group II" (Kesminas and Virbickas 2000, Virbickas and Kesminas 2007).

Table 1

Comparison of environmental variables' characteristics in natural and regulated stretches surveyed in the Nevėžis River

\begin{tabular}{|c|c|c|c|c|}
\hline \multirow{2}{*}{ Physicochemical conditions } & \multicolumn{2}{|c|}{ Riverbed morphology } & \multirow{2}{*}{$t$-test value } & \multirow{2}{*}{$P$ value } \\
\hline & Natural & Regulated & & \\
\hline Distance from confluence $[\mathrm{km}]$ & $154.1 \pm 1.1$ & $181.0 \pm 1.9$ & 12.71 & $<0.001$ \\
\hline Watershed area $\left[\mathrm{km}^{2}\right]$ & $331.9 \pm 48.9$ & $179.1 \pm 14.1$ & 3.00 & 0.039 \\
\hline Macrophyte coverage [\%] & $35.0 \pm 2.3$ & $76.0 \pm 3.8$ & 8.91 & $<0.001$ \\
\hline Canopy cover $[\%]$ & $30.0 \pm 2.8$ & $5.0 \pm 1.7$ & 7.42 & 0.002 \\
\hline Channel width [m] & $15.0 \pm 1.7$ & $13 \pm 1.2$ & 0.96 & 0.391 \\
\hline Mean depth $[\mathrm{m}]$ & $0.4 \pm 0.1$ & $1.0 \pm 0.0$ & 5.19 & 0.006 \\
\hline Flow velocity $\left[\mathrm{m} \cdot \mathrm{s}^{-1}\right]$ & $0.4 \pm 0.1$ & $0.1 \pm 0.0$ & 8.00 & 0.001 \\
\hline Discharge $\left[\mathrm{m}^{3} \cdot \mathrm{s}^{-1}\right]$ & $6.3 \pm 0.4$ & $1.3 \pm 0.1$ & 12.63 & $<0.001$ \\
\hline Suspended solids $\left[\mathrm{mg} \cdot \mathrm{L}^{-1}\right]$ & $2.7 \pm 0.2$ & $6.1 \pm 0.5$ & 11.60 & $<0.001$ \\
\hline $\mathrm{BOD}_{7}\left[\mathrm{mg} \mathrm{O}_{2} \cdot \mathrm{L}^{-1}\right]$ & $1.5 \pm 0.2$ & $2.2 \pm 0.2$ & 2.46 & 0.069 \\
\hline Total N $\left[\mathrm{mg} \cdot \mathrm{L}^{-1}\right]$ & $3.5 \pm 0.4$ & $5.7 \pm 0.5$ & 3.35 & 0.028 \\
\hline Total P $\left[\mathrm{mg} \cdot \mathrm{L}^{-1}\right]$ & $0.07 \pm 0.0$ & $0.19 \pm 0.0$ & 5.64 & 0.004 \\
\hline Bottom substrate & stones - gravel & sand - silt & 4.65 & $<0.001$ \\
\hline
\end{tabular}

As data on the bottom substrate were non-parametric, Mann-Whitney U test was used for the comparison of mean values. 
Table 2

Fish species in respective length classes studied for stable isotope analyses

\begin{tabular}{clccrc}
\hline \multirow{2}{*}{ Functional feeding group } & \multirow{2}{*}{ Species } & \multicolumn{2}{c}{ Length class } & TL range [mm] & $N$ \\
\cline { 3 - 4 } & & Class & TL [mm] & & \\
\hline Benthivorous & Rutilus rutilus & I & $<150$ & $50-147$ & 18 \\
& & II & $>150$ & $167-260$ & 18 \\
\multirow{2}{*}{ Piscivorous } & Perca fluviatilis & I & $<150$ & $90-143$ & 18 \\
& Perca fluviatilis & II & $>150$ & $175-202$ & 15 \\
& Esox lucius & I & $<250$ & $215-240$ & 12 \\
& & II & $>250$ & $285-340$ & 9 \\
\hline
\end{tabular}

$\mathrm{TL}=$ total length, $N=$ number of replicates.

Stable isotope analysis. The major primary sources were collected by hand from submerged rocks or logs in all available habitats on a given site, including leaves from riparian trees, aquatic macrophytes, filamentous green algae (Cladophora sp.). For periphyton, acid-washed $(10 \% \mathrm{HCl})$ filters were used to remove inorganic carbon. We rinsed macroalgae with deionized water and then removed invertebrates and particulate matter. All samples were placed into separate vials, then kept on ice in the field and subsequently frozen until prepared for stable isotope analysis. A small piece of fish white muscle tissue was dissected posteriorly to the dorsal fin and dried at $60^{\circ}$ $\mathrm{C}$ for $48 \mathrm{~h}$, homogenised (ground to fine powder) using an agate pestle and a mortar, and assigned to 3-6 analytical replicates (3-5 individuals of each taxonomic/size group per replicate), which were weighed in tin cups and combusted with an elemental analyser (FlashEA 1112) connected to an isotope ratio mass spectrometer (Thermo Finnigan Delta Plus Advantage). Carbon and nitrogen isotope data are reported as $\delta \mathrm{X}$ values (where $\mathrm{X}$ represents the heavier isotope ${ }^{13} \mathrm{C}$ or ${ }^{15} \mathrm{~N}$ ) or differences from the given standards, expressed in parts per thousand (\%o) and are calculated according to the formula:

$$
\delta \mathrm{X}=\left(R_{\text {sample }} \times R_{\text {standard }}^{-1}-1\right) \times 10^{-3}
$$

where $R_{\text {sample }}$ is the ${ }^{13} \mathrm{C} \div{ }^{12} \mathrm{C}$ ratio or ${ }^{15} \mathrm{~N} \div{ }^{14} \mathrm{~N}$ of sample, $R_{\text {standard }}={ }^{13} \mathrm{C} \div{ }^{12} \mathrm{C}$ or ${ }^{15} \mathrm{~N} \div{ }^{14} \mathrm{~N}$ of standard. The global references were atmospheric $\mathrm{N}_{2}$ for the ${ }^{15} \mathrm{~N} \div{ }^{14} \mathrm{~N}$ ratio, and Vienna Pee Dee belemnite for the ${ }^{13} \mathrm{C} \div{ }^{12} \mathrm{C}$ ratio. Typical precision for a single analysis was $\pm 0.2 \%$ for $\delta^{13} \mathrm{C}$ and \pm $0.3 \%$ for ${ }^{15} \mathrm{~N}$.

Statistical analysis. Comparisons of the environmental variables, carbon and nitrogen isotope ratios between natural and channelized river sites were performed using a paired $t$-test. Variation in spatial fish $\delta^{13} \mathrm{C}$ and $\delta{ }^{15} \mathrm{~N}$ isotopic values with habitat and environmental variables on natural and regulated study sites in the Nevėžis River was summarized through the principal components analysis (PCA). To present PCA results, we calculated eigenvalues, loading factors (at level $>0.5$ ) and projected them onto two first factors presented as a factors' biplot. The mean difference in stable isotope values among fish species was analysed using one-way ANOVA and Tukey's HSD test. Statements of statistical significance refer to $P$
$<0.05$. All species data were $\log (1+x)$ transformed prior to analysis. Calculations were done with Statistica for Windows, Version 6.0 (StatSoft, Tulsa, Oklahoma, USA).

\section{RESULTS}

Fish surveys. The TL of the fish analysed ranged from 50 to $260 \mathrm{~mm}$ for roach, from 90 to $202 \mathrm{~mm}$ for perch, and from 215 to $340 \mathrm{~mm}$ for pike. Overall, individuals of each fish species were clearly divided into two distinct groups by their feeding mode and $\delta^{13} \mathrm{C}-\delta^{15} \mathrm{~N}$ signatures. To illustrate isotopic variation in size, perch, roach, and pike specimens were subsequently classified into length classes I and II (Table 2).

Fish individuals assigned to the first group exhibited depleted $\delta^{13} \mathrm{C}$ and $\delta^{15} \mathrm{~N}$ isotopic signatures compared to those of the second group and included mostly benthivorous fish, except pike. The second group of fish had considerably enriched $\delta^{13} \mathrm{C}$ and $\delta^{15} \mathrm{~N}$ signatures and included some individuals of benthivorous roach, piscivorous perch and pike. There were differences in $\delta^{15} \mathrm{~N}$ values among size classes of perch and pike ( $t$-test: $P<0.05)$, but no difference was recorded in $\delta^{15} \mathrm{~N}$ between different-sized roach. With respect to roach, there was no difference in $\delta^{13} \mathrm{C}$ between different-sized fish ( $t$-test: $P<0.05)$.

Benthivorous fish collected from natural and regulated sites had significantly different mean $( \pm \mathrm{SD})$ nitrogen isotope ratios $\left(\delta^{15} \mathrm{~N}\right.$ for regulated $15.90 \% \mathrm{~m} \pm 1.34 \%$ and $13.75 \% \mathrm{~m} \pm$ $1.55 \%$ for natural sites; $t=-3.18, P<0.001, \mathrm{df}=18$ ). As for carbon isotope ratios, the difference was also significant $\left(\delta^{13} \mathrm{C}\right.$ for regulated $-33.01 \%$ $\pm 0.71 \%$ and $-31.82 \%$ o \pm $1.15 \%$ o for natural sites; $t=4.59, P<0.001, \mathrm{df}=18$ ) (Fig. 2).

As for piscivorous fish, the difference in $\delta^{15} \mathrm{~N}$ values was significant between natural $(14.17 \%$ o $\pm 1.74 \%$ ) and regulated $(15.68 \% \pm \pm 1.10 \%)$ sites $(t=-2.20, P<0.05$, $\mathrm{df}=16)$. The decrease in $\delta^{13} \mathrm{C}$ values was also significant: from $-30.02 \%$ $\pm 0.83 \%$ on natural, to $-32.06 \% \pm 0.46 \%$ on regulated sites $(t=6.24, P<0.001, \mathrm{df}=16)$. Piscivorous fish were consistently found enriched in $\delta^{13} \mathrm{C}$ compared with benthivorous fish $(P<0.001)$. However, there was no statistically significant difference in $\delta^{15} \mathrm{~N}$ values found between benthivorous and piscivorous fishes $(P>0.05)$.

Algal carbon isotope ratios from all investigated sites in the Nevèžis River were more depleted (mean $\delta^{13} \mathrm{C}=-34.2 \%$ $\pm 0.1 \%$ o) than those from terrestrial (riparian) sources (mean $\delta^{13} \mathrm{C}=-29.0 \%$ o $\pm 0.2 \%$ ). However, there was no statistically 


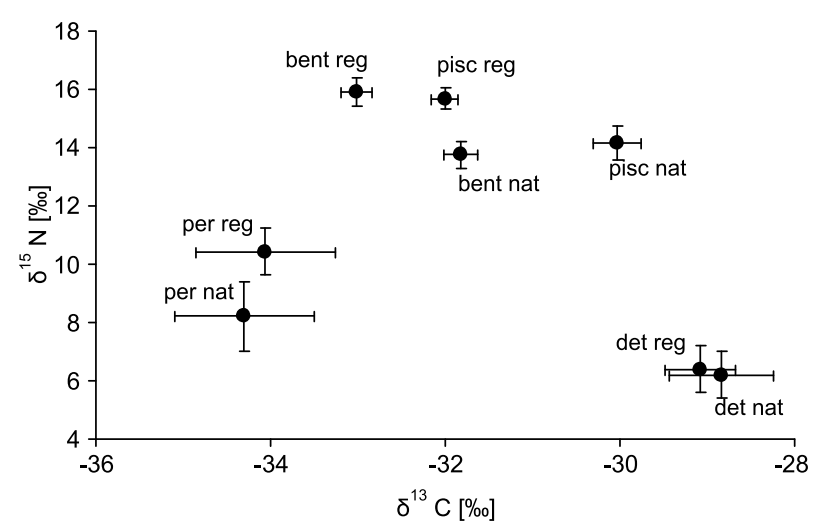

Fig. 2. Mean $( \pm \mathrm{SE})$ carbon and nitrogen isotope ratios for benthivorous (bent) and piscivorous (pisc) fish, perphyton (per) and detritus (det) collected from natural (nat) and regulated (reg) stretches of the Nevèžis River

significant difference in isotope ratios of terrestrial detritus $(P>0.05)$ collected from natural and regulated sites. The mean $\delta^{15} \mathrm{~N}$ values of periphyton $\left(\delta^{15} \mathrm{~N}=9.31 \% \pm 1.22 \%\right.$ ) were higher than those of terrestrial detritus on all sites $\left(\delta^{15} \mathrm{~N}=6.3 \% \pm 0.17 \% ; t=-5.99, P<0.001, \mathrm{df}=10\right)$ (Fig. 2). Neither $\delta^{13} \mathrm{C}(t=-1.50, P=0.205, \mathrm{df}=4)$ nor $\delta^{15} \mathrm{~N}(t=-$ $4.15, P=0.060, \mathrm{df}=4)$ of periphyton significantly differed between natural and regulated reaches. Likewise, neither $\delta^{13} \mathrm{C}(t=-1.47, P=0.194, \mathrm{df}=4)$ nor $\delta^{15} \mathrm{~N}(t=-3.61, P=$ $0.100, \mathrm{df}=4)$ of terrestrial detritus were different between natural and regulated reaches.

Mean stable isotope values differed among fish species on both natural (one-way ANOVA: $\delta^{13} \mathrm{C}, F_{5,13}=43.72, P<$ $0.001 ; \delta^{15} \mathrm{~N}, F_{5,13}=19.19, P<0.001$ ) and regulated (oneway ANOVA: $\delta^{13} \mathrm{C}, F_{5,13}=20.39, P<0.001 ; \delta^{15} \mathrm{~N}, F_{5,13}=$ 55.02, $P<0.001)$ sites.

Mean $\delta^{13} \mathrm{C}$ values of roach, perch, and pike from natural sites were higher than those from regulated sites, whereas mean values of $\delta^{15} \mathrm{~N}$ of the above mentioned fish from natural sites were lower than those from the regulated ones. $\delta^{13} \mathrm{C}$ of fish on regulated sites was significantly lower than that of fishes on natural sites $(P<0.05)$ and generally close to that of algal carbon collected from the same site. Roach of group I were the most ${ }^{13} \mathrm{C}$-depleted (natural: mean $=-32.40 \% \pm 0.2 \%$, regulated: mean $=$ $-33.58 \% \pm 0.2 \%$ ) of all other fish. Meanwhile, pike of group II had ${ }^{13} \mathrm{C}$-enriched mean values (natural: $-29.06 \%$ $\pm 0.3 \%$, regulated: $-31.73 \%$ $\pm 0.2 \%$ ) (Table 3 ).

Predatory fish were ${ }^{15} \mathrm{~N}$-enriched in comparison with benthivorous fish species. The mean $\delta^{15} \mathrm{~N}$ value of perch belonging to group I (natural $-12.17 \%$ o $\pm 0.2 \%$, regulated $-13.67 \%$ o $\pm 0.3 \%$ ) was depleted compared with other fish. The most enriched in $\delta^{15} \mathrm{~N}$ of all other fishes were pike of group II on natural and roach of group II on regulated sites (Table 3). Pike was considered to be the top predator in food chains of the Nevėžis River.

All fish species on natural sites were more ${ }^{13} \mathrm{C}$-enriched indicating their foraging for terrestrial (riparian) food sources. The mean $\delta^{13} \mathrm{C}$ value of fish on natural sites was more similar to that of detritus than to that of algae. Fish on regulated sites show depletion in $\delta^{13} \mathrm{C}$, suggesting that the basal resources for aquatic invertebrates (which we did not collect) are not derived from terrestrial detritus. In general, on regulated sites, all fish species, except for perch and pike of group II, exhibited the most ${ }^{15} \mathrm{~N}$-enriched values.

To verify the relations between fish $\delta^{13} \mathrm{C}$ and $\delta^{15} \mathrm{~N}$ isotopic signatures and environmental variables (fifteen variables were tested in total), the principal component analysis (PCA) was performed in the first place. The PCA extracted eleven factors, of which the first two factors showed eigenvalues $>1$ (Table 4). The first three extracted factors explained $89.8 \%$ of the variance. Macrophyte coverage, discharge, flow velocity, suspended solids, distance from the confluence, total $\mathrm{P}$, canopy cover, total $\mathrm{N}$, mean depth, $\mathrm{BOD}_{7}$ watershed area, bottom substrate, $\delta^{13} \mathrm{C}$, and $\delta^{15} \mathrm{~N}$ were strongly related to factor 1 (eigenvalues $>0.5$ ). PC 1 described the gradient from regulated sites with poor water quality to pristine natural sites with relatively good water quality. Regulated sites in agricultural landscape generally had the highest macrophyte coverage, suspended solids, the largest distance from the confluence, total $\mathrm{P}$, total $\mathrm{N}$, mean depth, and $\mathrm{BOD}_{7}$ values. Natural site groups generally exhibited low macrophyte coverage, suspended solids, total $\mathrm{P}$ and total $\mathrm{N}$ values and high flow velocity values. PC 2 separated sites on the basis of river channel width, watershed area, bottom substrate and $\mathrm{BOD}_{7}$.

Table 3

Comparison of isotopic variation of different fish size groups from natural and regulated sites in the Nevěžis River.

Paired t-tests were used to compare isotopic parameters between natural and regulated study sites,

\begin{tabular}{|c|c|c|c|c|c|c|c|c|}
\hline \multirow{2}{*}{ Species } & \multirow{2}{*}{$\mathrm{LC}$} & \multirow{2}{*}{ FFG } & \multicolumn{2}{|c|}{$\delta^{13} \mathrm{C}[\% 0]$} & \multirow{2}{*}{$\begin{array}{c}P \text { value } \\
\text { ( } t \text {-test })\end{array}$} & \multicolumn{2}{|c|}{$\delta^{15} \mathrm{~N}[\% 0]$} & \multirow[t]{2}{*}{$\begin{array}{c}P \text { value } \\
\text { ( } t \text {-test })\end{array}$} \\
\hline & & & Natural & Regulated & & Natural & Natural & \\
\hline Rutilus rutilus & I & B & $-32.40 \pm 0.2$ & $-33.58 \pm 0.2$ & 0.05 & $13.79 \pm 0.5$ & $16.54 \pm 0.1$ & 0.05 \\
\hline Rutilus rutilus & II & B & $-31.72 \pm 0.1$ & $-32.72 \pm 0.1$ & 0.05 & $15.26 \pm 0.1$ & $17.28 \pm 0.1$ & 0.05 \\
\hline Perca fluviatilis & I & B & $-31.13 \pm 0.1$ & $-32.55 \pm 0.1$ & 0.05 & $12.17 \pm 0.2$ & $13.67 \pm 0.3$ & 0.05 \\
\hline Perca fluviatilis & II & $\mathrm{P}$ & $-30.18 \pm 0.2$ & $-31.73 \pm 0.2$ & 0.05 & $14.08 \pm 0.4$ & $15.39 \pm 0.4$ & n.s. \\
\hline Esox lucius & I & $\mathrm{P}$ & $-30.83 \pm 0.1$ & $-32.51 \pm 0.1$ & 0.05 & $12.25 \pm 0.1$ & $14.65 \pm 0.1$ & 0.05 \\
\hline Esox lucius & II & $P$ & $-29.06 \pm 0.3$ & $-31.73 \pm 0.2$ & 0.05 & $16.17 \pm 0.2$ & $17.02 \pm 0.2$ & n.s. \\
\hline
\end{tabular}

$\mathrm{LC}=$ length class (as defined in Table 1), $\mathrm{FFG}=$ Functional feeding group, $\mathrm{B}=$ benthivorous, $\mathrm{P}=$ piscivorous, $\mathrm{n} . \mathrm{s} .=$ not significant. 
Table 4 affecting fish $\delta^{13} \mathrm{C}$ and $\delta^{15} \mathrm{~N}$ values (e.g., Grey et al.

Loading values for the first two factors and 17 variables with eigenvalues extracted by the principal component analysis

\begin{tabular}{|c|c|c|}
\hline Variable & Factor 1 & Factor 2 \\
\hline$\delta^{13} \mathrm{C}[\%]$ & 0.64 & -0.24 \\
\hline$\delta^{15} \mathrm{~N}[\% 0]$ & -0.58 & -0.21 \\
\hline Mean depth $[\mathrm{m}]$ & -0.85 & -0.49 \\
\hline Flow velocity $\left[\mathrm{m} \cdot \mathrm{s}^{-1}\right]$ & 0.96 & -0.24 \\
\hline Discharge $\left[\mathrm{m}^{3} \cdot \mathrm{s}^{-1}\right]$ & 0.97 & -0.21 \\
\hline Suspended solids $\left(\mathrm{mg} \cdot \mathrm{L}^{-1}\right)$ & -0.96 & -0.18 \\
\hline $\mathrm{BOD}_{7}\left[\mathrm{mg} \mathrm{O}_{2} \cdot \mathrm{L}^{-1}\right]$ & -0.82 & -0.53 \\
\hline Total N $\left[\mathrm{mg} \cdot \mathrm{L}^{-1}\right]$ & -0.89 & -0.39 \\
\hline Total P $\left(\mathrm{mg} \cdot \mathrm{L}^{-1}\right)$ & -0.94 & 0.22 \\
\hline Macrophyte coverage [\%] & -0.98 & -0.13 \\
\hline Canopy cover $[\%]$ & 0.94 & -0.32 \\
\hline Channel width [m] & 0.38 & -0.90 \\
\hline Watershed area $\left[\mathrm{km}^{2}\right]$ & 0.80 & -0.54 \\
\hline Distance from confluence $[\mathrm{km}]$ & -0.96 & 0.19 \\
\hline Bottom substrate & 0.80 & 0.53 \\
\hline Eigenvalue & 10.91 & 2.55 \\
\hline Total variance $[\%]$ & 72.76 & 17.03 \\
\hline
\end{tabular}

Values in bold type are loading factors (at level $>0.5$ ).

\section{DISCUSSION}

The majority of rivers and streams flow through open agricultural landscapes, due to which they are heavily affected by human activities, i.e., channelization, pollution (Kesminas and Virbickas 2000). The Nevěžis River, whose upper sections are channelized, is not an exception either (Kilkus and Stonevičius 2011).

In the presently reported study, we used physicochemical characteristics and stable isotope composition of fish tissues as well as multivariate analysis to assess the impact of anthropogenic activities along the upper reaches of the Nevėžis River. Environmental elements revealed that the ecological status of the river in regulated stretches was worse than in natural ones. Physicochemical characteristics and fish stable isotope composition clearly responded to changes in riparian morphology characteristics. Studies such as this one into European and more particularly into Baltic rivers are scarce (Sullivan et al. 2015, Čivas et al. 2016, Kautza and Sullivan unpublished*), whereas it is the first detailed research work revealing influence of the riverbed morphology on the source of organic material and the trophic structure of fish community along the Nevėžis River, using stable isotope analysis method.

Stable isotope ratios differed statistically among fish functional feeding groups, with predators having higher nitrogen isotope ratios than benthivorous fish within each river section. This result is consistent with trophic shifts of isotope ratios reported by other studies (McCutchan et al. 2003, Duda et al. 2011) and is likely to be a reflection of differences in food sources among these groups.

As many fish species undergo ontogenetic shifts in the feeding niche, fish size is another factor possibly 2001, Post 2002). Persson and Hansson (1999) found that large perch were exclusively piscivorous and had, accordingly, significantly higher $\delta^{15} \mathrm{~N}$ values than roach or other size classes of perch. Differences between the diet of roach belonging to different size-classes and that of perch of smaller classes were too slight to be traced in the stable isotope content. Likewise, we also found that there were differences in $\delta^{15} \mathrm{~N}$ values among sizeclasses of perch and pike, but there was no difference in $\delta^{15} \mathrm{~N}$ between different-sized roach. There was a positive relation between fish length and $\delta^{15} \mathrm{~N}$ of fishes. Similar results have been found for other fish species and are often attributed to either an ontogenetic change in the diet or to differential metabolic fractionation of nitrogen with age (Beaudoin et al. 1999, Overman and Parrish 2001). The trophic shift of $\mathrm{N}$ was higher for carnivores and other consumers with high-protein diets (vertebrates, microbes, and animal-based prepared diets) than for consumers with plant or algal diets (including plant-based prepared diets), but not so significantly (McCutchan et al. 2003).

Top predators such as the northern pike $\left(\delta^{15} \mathrm{~N}=\right.$ $12.5 \%$ ), and the big European perch $\left(\delta^{15} \mathrm{~N}=12.2 \%\right.$ ), were plotted at the top, while benthivorous roach $\left(\delta^{15} \mathrm{~N}=\right.$ $10.1 \%$ ), remained at the bottom of the isotopic niche of Drūkšiai Lake (Lithuania) (Rakauskas 2014).

We found that $\sim \delta^{15} \mathrm{~N}$ values differed by $2 \%{ }_{0}-4 \%$ o between the two size groups of fish (carnivorous/benthivorous), which is consistent with findings by Camusso et al. (1999) who reported that this isotope shift indicates that these groups of animals are at different trophic levels. Similar isotope compositions in different fish species reflect either similar feeding strategies or that one or both species feed on a variety of sources incorporating a wide range of isotope compositions. The low $\delta^{15} \mathrm{~N}$ values in small roach and small perch suggested the presence of plants and zooplankton in their diet and similar feeding strategies; whereas the high values in pike (which is carnivorous) and large roach (which is omnivorous, feeding on algae, macrophyte detritus and insects) probably reflect different food sources that nonetheless integrate to give similar isotopic compositions (Camusso et al. 1999).

As expected before, algae and terrestrial detritus differed significantly in their $\delta^{13} \mathrm{C}$ values in both investigated stretches of the river. However, they did not differ significantly in their isotope ratios between natural and regulated stretches. Terrestrially derived $\mathrm{C} 3$ organic matter has mean $\delta^{13} \mathrm{C}$ between $-20 \%$ and $-32 \%$ (mean: $-27 \%$ ) (Leng and Marshall 2004). The mean $\delta^{15} \mathrm{~N}$ value of terrestrial detritus in the Nevěžis River was $-29.0 \%$. The mean $\delta^{15} \mathrm{~N}$ values of periphyton were higher than those of terrestrial detritus across all sites.

Algal carbon isotope ratios from all the investigated sites in the Nevėžis River were more ${ }^{13} \mathrm{C}$-depleted (mean $\delta^{13} \mathrm{C}=-34.2 \%$ $\pm 0.1 \%$ o) than those of terrestrial (riparian) sources (mean $\delta^{13} \mathrm{C}=-29.0 \%$ $\pm 0.2 \%$ ) and were within the range of previously reported values (Fry 1984, Harrigan et al. 1989, Lee 1995, Boon et al. 1997, Bouillon 
et al. 2002). However, there was no statistically significant difference in isotope ratios of terrestrial detritus collected from natural and regulated sites. The mean $\delta^{15} \mathrm{~N}$ values of periphyton $\left(\delta^{15} \mathrm{~N}=9.31 \% \mathrm{0} \pm 1.22 \%\right.$ ) were higher than those of terrestrial detritus across all sites $\left(\delta^{15} \mathrm{~N}=6.3 \%\right.$ $0.17 \%$; $t=-5.99, P<0.001, \mathrm{df}=10)$. This is consistent with the findings of Angradi (1994), who indicated that dual isotope plots reveal that lotic algae, riparian vegetation, and upland vegetation had distinct isotope signatures.

According to Kruk (2007) pike and roach did not respond to changes in the quality of the aquatic environment. Conversely, we found that $\delta^{15} \mathrm{~N}$ values of roach, perch, and pike followed an upward trend from natural to regulated sites. According to Andersson and Cabana (2005), $\delta^{15} \mathrm{~N}$ in aquatic organisms would increase in a predictable way, following the increasing amounts of agricultural $\mathrm{N}$ inputs. Comparable relations between $\delta^{15} \mathrm{~N}$ of indicator organisms and agricultural land use were observed in previous studies (Harrington et al. 1998, Hebert and Wassenaar 2001, Udy and Bunn 2001). Our results complement these studies as longitudinal trends within watersheds can help us to better understand how progressive changes in land use affect $\delta^{15} \mathrm{~N}$. Furthermore, the use of organisms of different trophic levels may help to distinguish those components of the food web that are affected by anthropogenic activities from those that avoid them through migration (Anderson and Cabana 2005).

All fish species on natural sites were more ${ }^{13} \mathrm{C}$-enriched indicating their foraging for terrestrial (riparian) food sources. Similarly to our results, blacknose dace, Rhinichthys atratulus (Hermann, 1804); and brown trout, Salmo trutta Linnaeus, 1758, the only species collected on both forested and unforested sites, was more negative by $3 \%$ on the unforested site, implying a greater dependence on autochthonous carbon. Despite that, there is very little overall difference in absolute fish $\delta^{13} \mathrm{C}$ between sites (Rosenfeld and Roff 1992). Fish from natural stretches would therefore appear to derive more of their carbon base from terrestrial sources than aquatic invertebrates from the same site. This suggests that terrestrial inputs in the form of infalling invertebrates (secondary producers) may contribute to vertebrate production in a forested stream as much as primary terrestrial carbon inputs (leaves, detritus) via the aquatic food chain do (Rosenfeld and Roff 1992).

Our findings from the field experiment are consistent with previous studies of middle-sized rivers that report enhanced algal and macrophyte growth with $\mathrm{P}$ supplementation, even in heavily shaded river sections (Taulbee at al. 2005, Hill and Fanta 2008). Similarly to previous studies (Briand and Cohen 1987, Schoener 1989, Vander Zanden and Fetzer 2007, Sullivan et al. 2015), we found fish $\delta^{13} \mathrm{C}$ and $\delta^{15} \mathrm{~N}$ isotopic signatures to differ significantly among riverbed morphology types, with the PCA model explaining almost $90 \%$ of the variation.

In conclusion, our results showed that $\delta^{15} \mathrm{~N}$ and $\delta^{13} \mathrm{C}$ of fish at different trophic levels reacted strongly to spatial patterns in the intensity of eutrophication associated with $\mathrm{N}$ and $\mathrm{P}$ inputs, agricultural land use and channelization within and among watersheds. Furthermore, they reveal that within-site variation in $\delta^{15} \mathrm{~N}$ among functional feeding groups remained small compared with among-site variation, thus supporting the general use of $\delta^{15} \mathrm{~N}$ values of fish as landscape integrators of the impact of land use on aquatic ecosystems (Andersson and Cabana 2005).

Agricultural land use has caused marked changes in the stable isotope composition of perch, roach, and pike populations in the investigated Lithuanian river. Fish on regulated sites show depletion in $\delta^{13} \mathrm{C}$, suggesting that the basal resources for aquatic invertebrates (which we did not collect) are not derived from terrestrial detritus. The overall $\delta^{13} \mathrm{C}$ values of fish in channelized stretches are usually lower than those in natural ones and are generally close to those of algal carbon. Similarly to previous studies (Rosenfeld and Roff 1992, Angradi 1994, Coat et al. 2009, Sullivan et al. 2015) the fish assemblages of natural stretches were found to be more ${ }^{13} \mathrm{C}$-enriched indicating their feeding on the terrestrial (riparian) food sources. Fish from the natural sites had isotopic labels much closer to terrestrial one than to aquatic carbon. Our results, together with those of the previous studies, suggest that isotopic variation of fish coupled with hydrological changes in middle-sized rivers is a common phenomenon and is associated with allochthonous organic input and autochthonous phytoplankton growth (Mariotti et al. 1991, Barth et al. 1998, Kendall et al. 2001).

\section{ACKNOWLEDGMENTS}

The authors would like to thank Dr. Gintautas Vaitonis for providing vector graphic figures. The authors are grateful to Laima Monkiene for additional editing of English language of the revised manuscript.

\section{REFERENCES}

Anderson C., Cabana G. 2005. $\delta^{15} \mathrm{~N}$ in riverine food webs: Effects of $\mathrm{N}$ inputs from agricultural watersheds. Canadian Journal of Fisheries and Aquatic Science 62 (2): 333-340.

DOI: $10.1139 / \mathrm{f0} 4-191$

Angradi T.R. 1994. Trophic linkages in the lower Colorado River: Multiple stable isotope evidence. Journal of the North American Benthological Society 13 (4): 479495. DOI: $10.2307 / 1467845$

Anonymous 1985. Standard methods for the examination of water and wastewater. American Public Health Association, Washington, DC, USA.

Arbačiauskas K., Balčiauskas L., Baltrūnaitė L., Baranauskas K., Ivinskis P., Juškaitis R., Kesminas V., Kurlavičius P., Ložys L., Naruševičius V., Rakauskas V., Repečka R., Rimšaitė J., Skujienė G., Stanevičius V., Steponėnas A., Trakimas G., Ulevičius A., Vaivilavičius G., Virbickas T. 2009. Gyvūnijos monitoringo metodai. [Methods of fauna monitoring.] Vilniaus universiteto Ekologijos institutas, Vilnius, Lithuania. [In Lithuanian.]

Barth J.A., Veizer C.J., Mayer B. 1998. Origin of particulate organic carbon in the upper St. Lawrence: 
Isotopic constraints. Earth and Planetary Science Letters 162 (1-4): 111-121.

DOI: $10.1016 / \mathrm{S} 0012-821 \mathrm{X}(98) 00160-5$

Beaudoin C.P., Tonn W.M., Prepas E.E., Wassenaar L.I. 1999. Individual specialization and trophic adaptability of northern pike (Esox lucius): An isotope and dietary analysis. Oecologia 120 (3): 386-396.

DOI: $10.1007 / \mathrm{s} 004420050871$

Bis B., Zdanowicz A., Zalewski M. 2000. Effect of catchments properties on hydrochemistry, habitat complexity and invertebrate community structure in a lowland river. Hydrobiologia 422 (0): 369-387. DOI: $10.1023 / \mathrm{A}: 1017002923173$

Bolnick D.I., Svanbäck R., Fordyce J.A., Yang L.H., Davis J.M., Hulsey C.D., Forister M.L. 2003. The ecology of individuals: Incidence and implications of individual specialization. The American Naturalist 161 (1): 1-28. DOI: $10.1086 / 343878$

Boon P.I., Bird F.L., Bunn S.E. 1997. Diet of the intertidal callianassid shrimps Biffarius arenosus and Trypea australiensis (Decapoda: Thalassinidea) in Western Port (southern Australia), determined with multiple stable-isotope analyses. Marine and Freshwater Research 48 (6): 503-511.

DOI: $10.1071 / \mathrm{MF} 97013$

Bouillon S., Koedam N., Raman A.V., Dehairs F. 2002. Primary producers sustaining macro-invertebrate communities in intertidal mangrove forests. Oecologia 130 (3): 441-448.

DOI: $10.1007 / \mathrm{s} 004420100814$

Briand F., Cohen J.E. 1987. Environmental correlates of food chain length. Science 238 (4829): 956-960.

DOI: $10.1126 /$ science. 3672136

Cabana G., Rasmussen J.B. 1996. Comparison of aquatic food chains using nitrogen isotopes. Proceedings of the National Academy of Sciences of the United States of America 93 (20): 10844-10847.

Camusso M., Balestrini R., Martinotti W., Arpini M. 1999. Spatial variations in trace metal and stable isotope content of autochthonous organisms and sediments in the river Po system (Italy). Aquatic Ecosystem Health and Management 2 (1): 39-53. DOI: $10.1080 / 14634989908656938$

Coat S., Monti D., Bouchon C., Lepoint G. 2009. Trophic relationships in a tropical stream food web assessed by stable isotope analysis. Freshwater Biology 54 (5): 1028-1041.

DOI: $10.1111 / \mathrm{j} .1365-2427.2008 .02149 . x$

Costanzo S.D., O'Donohue M.J., Dennison W.C., Loneragan N.R., Thomas M. 2001. A new approach for detecting and mapping sewage impacts. Marine Pollution Bulletin 42 (2): 149-156.

DOI: $10.1016 / \mathrm{S} 0025-326 \mathrm{X}(00) 00125-9$

Deniro M.J., Epstein S. 1981. Influence of diet on the distribution of nitrogen isotopes in animals. Geochimica et Cosmochimica Acta 45 (3): 341-351. DOI: 10.1016/0016-7037(81)90244-1

Čivas L., Kesminas V., Sullivan S.M.P. 2016. Influences of hydrogeomorphology and chemical water quality on fish assemblages in the Nevėžis River, Lithuania: Implications for river basin management plans in the Baltics. Environmental Monitoring and Assessment 188 (2): 1-16.

DOI: $10.1007 / \mathrm{s} 10661-016-5098-5$

Duda J.J., Coe H., Morley S., Kloehn K. 2011. Establishing spatial trends in water chemistry and stable isotopes $\left(\delta^{15} \mathrm{~N}\right.$ and $\left.\delta^{13} \mathrm{C}\right)$ in the Elwha River prior to dam removal and salmon recolonization. River Research and Applications 27 (10): 1169-1181. DOI: $10.1002 /$ rra.1413

Fry B. $1984 .{ }^{13} \mathrm{C} /{ }^{12} \mathrm{C}$ ratios and the trophic importance of algae in Florida Syringodium filiforme seagrass meadows. Marine Biology 79 (1): 11-19.

DOI: $10.1007 / \mathrm{BF} 00404980$

Fry B. 1988. Food web structure on Georges Bank from stable $\mathrm{C}, \mathrm{N}$, and $\mathrm{S}$ isotopic compositions. Limnology and Oceanography 33 (5): 1182-1190. DOI: $10.4319 /$ lo.1988.33.5.1182

Fry B. 2006. Stable isotope ecology. Springer, New York, NY, USA. DOI: $10.1007 / 0-387-33745-8$

Grey J., Jones R.I., Sleep D. 2001. Seasonal changes in the importance of the source of organic matter to the diet of zooplankton in Loch Ness, as indicated by stable isotope analysis. Limnology and Oceanography 46 (3): 505-513.

DOI: $10.4319 /$ lo.2001.46.3.0505

Harrigan P., Zieman J., Macko S.A. 1989. The base of nutritional support for the gray snapper (Lutjanus griseus): An evaluation based on a combined stomach content and stable isotope analysis. Bulletin of Marine Science 44 (1): 65-77.

Harrington R.R., Kennedy B.P., Chamberlain C.P., Blum J.D., Folt C.L. 1998. ${ }^{15} \mathrm{~N}$ enrichment in agricultural catchments: Field patterns and applications to tracking Atlantic salmon (Salmo salar). Chemical Geology 147 (3-4): 281-294.

DOI: $10.1016 / \mathrm{S} 0009-2541(98) 00018-7$

Hebert C.E., Wassenaar L.I. 2001. Stable nitrogen isotopes in waterfowl feathers reflect agricultural land use in western Canada. Environmental Science and Technology 35 (17): 3482-3487.

DOI: $10.1021 / \mathrm{es} 001970 \mathrm{p}$

Hill W.R., Fanta S.E. 2008. Phosphorus and light colimit periphyton growth at subsaturating irradiances. Freshwater Biology 53 (2): 215-225. DOI: $10.1111 /$ j.1365-2427.2007.01885.x

Hjelm J., Persson L., Christensen B. 2000. Growth, morphological variation and ontogenetic niche shifts in perch (Perca fluviatilis) in relation to resource availability. Oecologia 122 (2): 190-199. DOI: $10.1007 /$ PL00008846

Hjelm J., van de Weerd G.H., Sibbing F.A. 2003. Functional link between foraging performance, functional morphology, and diet shift in roach (Rutilus rutilus). Canadian Journal of Fisheries and Aquatic Sciences 60 (6): 700-709.

DOI: $10.1139 / \mathrm{f} 03-058$ 
Horppila J., Ruuhijärvi J., Rask M., Karppinen C., Nyberg K., Olin M. 2000. Seasonal changes in the diets and relative abundances of perch and roach in the littoral and pelagic zones of a large lake. Journal of Fish Biology 56 (1): 51-72.

DOI: $10.1111 /$ j.1095-8649.2000.tb02086.x

Jardine T.D., Kidd K.A., Fisk A.T. 2006. Applications, considerations, and sources of uncertainty when using stable isotope analysis in ecotoxicology. Environmental Science and Technology 40 (24): 7501-7511. DOI: $10.1021 / \mathrm{es} 061263 \mathrm{~h}$

Kendall C., Silva S.R., Kelly V.J. 2001. Carbon and nitrogen isotopic compositions of particulate organic matter in four large river systems across the United States. Hydrological Processes 15 (7): 1301-1346. DOI: 10.1002/hyp.216

Kesminas V., Virbickas T. 2000. Application of an adapted index of biotic integrity to rivers of Lithuania. Hydrobiologia 422 (0): 257270. DOI: $10.1023 / \mathrm{A}: 1017049728142$

Kilkus K., Stonevičius E. 2011. Lietuvos vandenų geografija; Vadovèlis. [The geography of Lithuanian waters; A textbook.] Vilniaus universitetas, Vilnius, Lithuania. [In Lithuanian.]

Kruk A. 2007. Role of habitat degradation in determining fish distribution and abundance along the lowland Warta River, Poland. Journal of Applied Ichthyology 23 (1): 9-18.

DOI: $10.1111 / \mathrm{j} .1439-0426.2006 .00784 . x$

Lee S.Y. 1995. Mangrove outwelling: A review. Hydrobiologia 295 (1): 203-212.

DOI: $10.1007 / \mathrm{BF} 00029127$

Leng M.J., Marshall J.D. 2004. Palaeoclimate interpretation of stable isotope data from lake sediment archives. Quaternary Science Reviews 23 (7-8): 811831.

DOI: 10.1016/j.quascirev.2003.06.012

Lesutienė J., Gorokhova E., Gasiūnaitė Z.R., Razinkovas A. 2007. Isotopic evidence for zooplankton as an important food source for the mysid Paramysis lacustris in the Curonian Lagoon, the south-eastern Baltic Sea. Estuarine, Coastal and Shelf Science 73 (1-2): 73-80.

DOI: $10.1016 /$ j.ecss.2006.12.010

Lesutienè J., Gorokhova E., Gasiūnaitė Z.R., Razinkovas A. 2008. Role of mysid seasonal migrations in the organic matter transfer in the Curonian Lagoon, south-eastern Baltic Sea. Estuarine, Coastal and Shelf Science 80 (2): 225-234.

DOI: 10.1016/j.ecss.2008.08.001

Mariotti A., Gadel F., Giresse P., Kinga-Mouzeo 1991. Carbon isotope composition and geochemistry of particulate organic matter in the Congo River (Central Africa): Application to the study of Quaternary sediments off the mouth of the river. Chemical Geology: Isotope and Geosiciencs section 86 (4): 345-357.

DOI: $10.1016 / 0168-9622(91) 90016-P$
McCutchan J.H., Lewis W.M.jr., Kendall C., McGrath C.C. 2003. Variation in trophic shift for stable isotope ratios of carbon, nitrogen, and sulfur. Oikos 102 (2): 378-390.

DOI: 10.1034/j.1600-0706.2003.12098.x

Minagawa M., Wada E. 1984. Stepwise enrichment of ${ }^{15} \mathrm{~N}$ along food chains: Further evidence and the relation between $\delta^{15} \mathrm{~N}$ and animal age. Geochimica et Cosmochimica Acta 48 (5): 1135-1140. DOI: $10.1016 / 0016-7037(84) 90204-7$

Nakamura F., Yamada H. 2005. The effects of pasture development on the ecological functions of riparian forests in Hokkaido in Nothern Japan. Ecological Engineering 24 (5): 539-550.

DOI: $10.1016 /$ j.ecoleng.2005.01.010

Overman N.C., Parrish D.L. 2001. Stable isotope composition of walleye: $\delta^{15} \mathrm{~N}$ accumulation with age and area-specific differences in $\delta^{13} \mathrm{C}$. Canadian Journal of Fisheries and Aquatic Sciences 58 (6): 1253-1260. DOI: 10.1139/f01-072

Paukštys B., Vaitiekūnienė J., Virbickas T., Daunys D., Taminskas J., Klimas A., Bukantis A., Povilaitis A., Punys P., Semènienè D. 2011. Lietuvos vandens telkiniu būklè ir ūkinès veiklos poveikis. [State and economic impact of Lithuanian waterbodies.] Vandens harmonija, Vilnius, Lithuania. [In Lithuanian.]

Persson A., Hansson L.-A. 1999. Diet shift following competitive release. Canadian Journal of Fisheries and Aquatic Sciences 56 (1): 70-78.

DOI: $10.1139 / \mathrm{f} 98-141$

Pilinkovskij A., Kesminas V., Bukelskis E., Čivas L. 2014. Ruffe (Gymnocephalus cernuus L.) growth and diet in Lake Dusia (southern Lithuania). Archives of Polish Fisheries 22 (2): 110-119. DOI: $10.2478 /$ aopf-2014-0010

Platts W.S., Megahan W.F., Minshall W.G. 1983. Methods for evaluating stream, riparian, and biotic conditions. General Technical Report INT-138, USDA Forest Service, Rocky Mountain Research Station, Ogden, UT, USA.

Pliūraitè V., Kesminas V. 2010. Response of benthic macroinvertebrates to agricultural pollution and channelization in the Mūša River, Lithuania. Fresenius Environmental Bulletin 19 (12a): 2929-2937.

Pliūraitė V., Virbickas T., Skrodenytė-Arbačiauskienė V. 2013. Changes in roach (Rutilus rutilus (L.)) diet and growth in relation to river water quality. Ekologija 59 (3): 134-141.

DOI: 10.6001/ekologija.v59i3.2796

Post D.M. 2002. Using stable isotopes to estimate trophic position: Models, methods, and assumptions. Ecology 83 (3): 703-718.

DOI:10.1890/0012-9658(2002)083[0703:USITET]2.0.CO;2

Rakauskas V. 2014. 10. Stable isotope study of the Lake Drūkšiai food web before the Ignalina Nuclear Power Plant closure. Zoology and Ecology 24 (2): 160-167. DOI: $10.1080 / 21658005.2014 .925233$

Rakauskas V., Pūtys Ž., Dainys J., Lesutienė J., Ložys L., Arbačiauskas K. 2013. Increasing population of 
the invader round goby, Neogobius melanostomus (Actinopterygii: Perciformes: Gobiidae), and its trophic role in the Curonian Lagoon, SE Baltic Sea. Acta Ichthyologica et Piscatoria 43 (2): 95-108. DOI: 10.3750/AIP2013.43.2.02

Rosenberg D.M., McCully P., Pringle C.M. 2000. Global-scale environmental effects of hydrological alternations: Introduction. Bioscience 50 (9): 746-752. DOI: 10.1641/0006-3568(2000)050[0746:GSEEOH]2.0.CO;2

Rosenfeld J.S., Roff J.C. 1992. Estimation of the carbon base in southern Ontario streams using stable isotopes. Journal of the North American Benthological Society 11 (1): 1-10.

DOI: $10.2307 / 1467877$

Sánchez-Hernández J., Servia M. J., Vieira-Lanero R., Cobo F. 2012. Ontogenetic dietary shifts in a predatory freshwater fish species: The brown trout as an example of a dynamic fish species. Pp. 271-298. In: Türker H. (ed.) Advances and contributions to fish biology. InTech.

DOI: $10.5772 / 54133$

Savage C., Elmgren R. 2004. Macroalgal (Fucus vesiculosus) $\delta^{15} \mathrm{~N}$ values trace decrease in sewage influence. Ecological Applications 14 (2): 517-526. DOI: $10.1890 / 02-5396$

Schoener T.W. 1989. Food webs from the small to the large: The Robert H. MacArthur Award Lecture. Ecology 70 (6): 1559-1589. DOI: $10.2307 / 1938088$

Svanbäck R., Eklöv P. 2002. Effects of habitat and food resources on morphology and ontogenetic growth trajectories in perch. Oecologia 131 (1): 61-70.

DOI: $10.1007 / \mathrm{s} 00442-001-0861-9$

Svanbäck R., Persson L. 2004. Individual diet specialization, niche width and population dynamics: Implications for trophic polymorphisms. Journal of Animal Ecology 73 (5): 973-982.

DOI: $10.1111 / \mathrm{j} .0021-8790.2004 .00868 . \mathrm{x}$

Syväranta J., Jones R.I. 2008. Changes in feeding niche widths of perch and roach following biomanipulation, revealed by stable isotope analysis. Freshwater Biology 53 (3): 425-434.

DOI: $10.1111 / \mathrm{j} .1365-2427.2007 .01905 . \mathrm{x}$
Sullivan S.M.P., Hossler K. Cianfrani C.M. 2015. Ecosystem structure emerges as a strong determinant of food-chain length in linked stream-riparian ecosystems. Ecosystems 18 (8): 1356-1372.

DOI: $10.1007 / \mathrm{s} 10021-015-9904-7$

Taulbee W.K., Cooper S.D., Melack J.M. 2005. Effects of nutrient enrichment on algal biomass across a natural light gradient. Archiv für Hydrobiologie 164 (4): 449-464.

DOI: $10.1127 / 0003-9136 / 2005 / 0164-0449$

Thoresson G. 1996. Guidelines for coastal fish monitoring. Kustrapport 1996:2. Fiseriverket Kustlaboratoriet, Öregrund, Sweden.

Trakimas G., Jardine T.D., Barisevičiūtė R., Garbaras A., Skipitytė R., Remeikis V. 2011. Ontogenetic dietary shifts in European common frog (Rana temporaria) revealed by stable isotopes. Hydrobiologia 675 (1): 87-95.

DOI: $10.1007 / \mathrm{s} 10750-011-0804-3$

Udy J.W., Bunn S.E. 2001. Elevated $\delta^{15} \mathrm{~N}$ values in aquatic plants from cleared catchments: why? Marine and Freshwater Research 52 (3): 347-351.

DOI: $10.1071 / \mathrm{MF} 00002$

Vander Zanden M.J., Fetzer W.W. 2007. Global patterns of aquatic food chain length. Oikos 116 (8): 1378-1388.

DOI: $10.1111 / \mathrm{j} .0030-1299.2007 .16036 . x$

Virbickas T., Kesminas V. 2007. Development of fishbased assessment method for the ecological status of rivers in the Baltic region. Fisheries Management and Ecology 14 (6): 531-539. DOI: $10.1111 /$ j.1365-2400.2007.00572.x

Žiliukas V. 1999. Ecological analysis of shore-zone fish fry communities of the Nemunas river Basin. Pp. 37-65. In: Volskis R. (ed.) Hydrobiological research in the Baltic countries. Part 1. Rivers and Lakes. UNESCO National Commissions of Estonia, Latvia and Lithuania, Vilnius.

Received: 8 March 2016

Accepted: 9 November 2016

Published electronically: 31 December 2016 